\title{
Feelings perceived by students during the phases of accounting dissertation guidance ${ }^{\star}$
}

\author{
Alison Martins Meurer1,2 \\ (D) https://orcid.org/0000-0002-3704-933X \\ Email: alisonmmeurer@gmail.com \\ Rayane Camila da Silva Sousa ${ }^{1}$ \\ (D) https://orcid.org/0000-0002-7181-1607 \\ Email: rayanecamila@ufpr.br \\ Flaviano Costa ${ }^{3}$ \\ (D) https://orcid.org/0000-0002-4694-618X \\ Email: flaviano@ufpr.br \\ Romualdo Douglas Colauto 3 \\ (D) https://orcid.org/0000-0003-3589-9389 \\ Email: rdcolauto.ufpr@gmail.com
}

\footnotetext{
1 Universidade Federal do Paraná, Programa de Pós-Graduação em Contabilidade, Curitiba, PR, Brazil

${ }^{2}$ Universidade Estadual de Ponta Grossa, Departamento de Contabilidade, Ponta Grossa, PR, Brazil

3 Universidade Federal do Paraná, Departamento de Ciências Contábeis, Curitiba, PR, Brazil
}

Received on 09.09.2019 - Desk acceptance on 09.27.2019 - $3^{\text {rd }}$ version approved on 03.05.2020

Editor-in-Chief: Fábio Frezatti

Associate Editor: Jacqueline Veneroso Alves da Cunha

\begin{abstract}
The aim of this study was to understand how students graduating from accounting master's courses perceived the feelings experienced in the different dissertation guidance phases. This investigation enables us to identify which stages generate negative feelings and to thus propose actions to improve the affective relationship between the advisor and student, considering that the feelings substantially affect the potential of the scientific works originating from that relationship. The advisor-student relationship and the feelings involved in it are among the main factors that positively or negatively affect the conclusion of the academic work, and understanding it is important in order to improve this interaction process. One of the implications of the research relates to the importance of stricto sensu programs monitoring the guidance process and somehow searching for mechanisms that promote harmony in the guidance process, as the experiences during the dissertation guidance process can affect the student's likelihood of continuing on their academic journey. For the data collection, a survey was conducted in which the participants used emojis to represent the feelings experienced in their relationship with the advisor during the construction of their master's dissertation. In addition, semi-structured interviews were carried out, which enabled the elaboration of a collective subject discourse regarding the feelings experienced during the dissertation guidance process. The 88 responses and eight interviews enabled the identification of feelings such as anxiety, fear, and insecurity in the first phases of the dissertation building. Abandonment, confusion, and frustration were felt in the last phases of the relationship with the advisor. Regarding the positive feelings, there are indications of joy, satisfaction, and calm, presenting greater frequency in the last stages of the dissertation. The collective subject discourses also indicated that the relationship with the advisor affected the quality of the scientific research and the student's academic trajectory.
\end{abstract}

Keywords: student-advisor relationship, feelings in higher education, master's, emojis, social representation.

Correspondence address

Alison Martins Meurer

Universidade Federal do Paraná, Programa de Pós-Graduação em Contabilidade

Avenida Prefeito Lothário Meissner, 632 - CEP 80210-170

Jardim Botânico - Curitiba - PR - Brasil

* Paper presented at the 19th USP International Conference in Accounting, São Paulo, SP, Brazil, July of 2019. 


\section{INTRODUCTION}

Teachers' behavior and the affective way in which they treat their students arouse motivation and interest in the teaching-learning process, leading to greater student participation and, consequently, better assimilation of the knowledge presented in the classroom. Moreover, teachers who express their affectivity and reach their students in a positive way improve social skills, help to develop the students, and promote unity and cooperation (Reis et al., 2012).

The attention paid to cognitive aspects instead of affective relationships has been a focus of discussions in the university environment (Veras \& Ferreira, 2010). Studies indicate that the relationship between teachers and students have been an influencer of the quality of the activities developed in post-graduation, especially regarding the guidance process for scientific works (Falaster et al., 2017). The advisor performs the role of guide in the student's academic journey; part of the student's success or lack of it can be attributed to their interactions with the advisor, transforming this relationship into a form of partnership in which the final product is the master's dissertation or doctoral thesis (Nóbrega, 2018).

The guidance process and the relationship between the advisor and student are investigated in the literature from various perspectives. Nóbrega (2018) addressed the relationship in academic guidance processes and the formal role of the advisor; Falaster et al. (2017) discussed the impact of the guidance on the future publications of PhD students; Massi and Giordan (2017) addressed the advisor's training; and Leite and Martins (2006) analyzed the influences of the advisor-student relationship on the production of theses and dissertations in business and accounting courses.

The evidence found in those studies revealed a lack of professionalization and formalization of the advisor figure (Massi \& Giordan, 2017; Nóbrega, 2018), it indicated the positive influence of the production of advisors on the quality of students' publications (Falaster et al., 2017), and it indicated students' lack of commitment and respect for deadlines and toward the stricto sensu activities, compromising the quality of the scientific research. In addition, these papers shed light on the existence of an autocratic and verticalized environment in which the guidance occurs asystematically and where the students experience feelings of anguish and insecurity.

The feelings originating from the guidance process form the core of this study, given that this element may somehow affect the behavior and activities carried out by the students, such as their relationship with the content addressed in the teaching environment (Mahoney \& Almeida, 2005; Tassoni \& Leite, 2013). Thus, this research specifically employs the concept of feeling as a constituent part of the affective dimension. Consequently, the theoretical scope of the research is based on Henri Wallon's (2007) Theory of Development, which places feelings within the affective domain, allowing for expression of the sensations felt based on certain experiences (GratiotAlfandéry, 2010).

The student's academic performance and their cognitive and affective development are influenced by a vast set of conditions that, in most cases, can be measured by the quality of the interpersonal relationships that occur in the school environment; among these is that of the teacher with the student, which is affected by variables such as beliefs, feelings, motivations, and abilities (Del Prette et al., 2005).

In a correlated study, Leite and Martins (2006) addressed the influence of the advisor-student relationship on the process of elaborating theses and dissertations in accounting post-graduate courses in the municipality of São Paulo. The reports highlighted the students' insecurity and solitude, in relation to the guidance process, caused primarily by a lack of interaction with and distance from their advisors. They discovered that advisors value students' technical characteristics, while students give a high level of importance to the personal and affective dimensions in their relationship with advisors.

Therefore, the discussions on the importance of the advisor-student relationship for the academic activities developed in stricto sensu and the importance of addressing the feelings originating from that process lead to the concern that guides this research: what are the feelings perceived by students graduating from accounting master's courses in the different dissertation guidance phases? Consequently, the aim of this research consisted of understanding how students finishing accounting master's courses perceived feelings experienced in the different dissertation guidance phases. Graudating students make up the body of analysis of the study as their feelings are consolidated over time, making this group more suitable for the analysis than students who are still in the middle of master's or $\mathrm{PhD}$ post-graduate courses.

In stricto sensu, the restructuring of the criteria of the institutional evaluation model used by the Coordination 
for the Improvement of Higher Education Personnel (Capes), while strengthening observation of the scientific production in quantitative terms, downplays the attention given to qualitative aspects (Nascimento, 2010). The interaction, partnership, comradeship, and friendship between the advisor and student, resulting from the longer time needed to build the work, take second place to a heteronomous, productivist, and superficial relationship due to the excess work given to the advisor and the demand for productivity indicators (Alves et al., 2012).

This misalignment has worried researchers, given that these relationships embody "the most concrete face of post-graduate programs, that is, it is the work of the teachers and students that results in the research and publications" (Nóbrega, 2018, p. 1056). Thus, this research is warranted as it enables an understanding of one of the aspects involved in the dynamism of the relationship that exists in guidance processes: the feelings developed among individuals who strive to build the scientific knowledge in the country and to obtain a prominent position within the universe of the most productive.

Observation of core elements of the knowledgebuilding process enables the construction of a social representation in order to outline the feelings originating from the guidance process and, consequently, to identify aspects that can be improved in this interaction. It is known that the quality of the advisor-student relationship is seen as one of the main factors that positively or negatively affect the conclusion of academic work (Alves et al., 2012). Nonetheless, there is a lack of investigations that address the guidance process in Brazil and abroad (Nóbrega, 2018). Levecque et al. (2017) also highlight the relevance of considering psychological aspects in the post-graduate environment, as the pressures that permeate it can affect students psychologically.

Specifically in business area courses, exploring the feelings experienced during dissertation guidance processes can contribute to an evaluation of the guidance conditions in which the scientific works are developed and explore these conditions to solve the interpersonal relationship conflicts that occur in this environment (Leite \& Martins, 2006). Dias et al. (2011) warn that a lack of pedagogical training of advisors can mean their guidance style is affected by the successful or unsuccessful experiences they have had with students, with feelings occupying a key role in this relationship.

\section{FEELINGS AND THE ADVISOR-STUDENT RELATIONSHIP}

Universities, previously seen as places of exclusive cognitive training, have sought to include affectivity in their educational practices, encouraging reflections on their place in the individual's entire human education (Ferreira \& Acioly-Régnier, 2010). Given the amplitude of the concepts that permeate affectivity, researchers with different interests have examined the theme from different perspectives, such as Henri Wallon (1941-2007), who highlighted affectivity as an essential dimension in knowledge building and of people over the course of their intellectual development (Veras \& Ferreira 2010).

Henri Wallon's (2007) Theory of Development unites affectivity and cognition so that they are dialectically in a constant dynamic, altering in the different stages of knowledge that the individual acquires during their existence (Gratiot-Alfandéry, 2010). Mahoney and Almeida (2005) explain that affectivity involves the individual's propensity to be affected through the external or internal environment by sensations that may be good or bad. In the Wallonian theory, there are three distinct moments that are consequences of organic and social elements in the evolution of affectivity: emotion, feeling, and passion.

Emotion is displayed through bodily expression and represented by the person's instantaneous attitudes.
Feeling, as the representational expression of affectivity, is displayed through mimicry or language. Passion is revealed as a form of behavioral self-control used to silence emotion, emerging with the evolution of mental representations (Mahoney \& Almeida, 2005; Veras \& Ferreira 2010).

The distinction between the concepts of emotion, feeling, and passion and their representations is one of the main contributions of Wallon's theory, which enabled affectivity to be defined as a functional domain composed of different moments that evolve over the course of development and that originate from the organic until reaching the cognitive, as can be observed in feelings (Ferreira \& Acioly-Régnier, 2010).

Specifically regarding feelings, Wallon argues that these do not imply sudden and momentaneous behaviors, like emotions do, as they are the opposite of these and tend to contain them (Veras \& Ferreira, 2010). In feelings, people have more mechanisms of representational expression, given that they analyze before assuming an attitude, they wait for the right moment to express themselves, and they intellectually portray their reasons and context in a more evolved way (Mahoney \& Almeida, 2005).

According to Tassoni and Santos (2013), the classroom environment is permeated by a dynamic of knowledge 
and feelings; this combination demonstrates that aspects of the affective domain are important for the teacher's training and for the development of effective pedagogical practices. For Pereira et al. (2016), feelings are assignable, representational, and consolidated over time; they correspond to the affectivity function and can be denominated and detailed more assertively in a study.

Silva (2005) used the Wallonian theory to study the relationship between the feelings and emotions of students and teachers in both theory and practical classes and the teaching-learning process. A large portion of the participants revealed that they believed that feelings and emotions influenced the teaching-learning process. The teachers reported feelings of pleasure, accomplishment, calm, and motivation, especially in the practical classes. The students described negative feelings associated with discouragement, displeasure, insecurity, anxiety, and fear in both the practical and theory classes. However, feelings related to motivation, pleasure, and accomplishment were reported more frequently in the practical classes.

With regard to the journey toward obtaining the master's or $\mathrm{PhD}$ title, the feelings originating from the advisor-student relationship are a constituent part of this affective dimension and are also present in the various stages of the student's education. Over the course of this journey, the student is led by a teacher-advisor (Nóbrega, 2018). Competence to guide a student goes beyond specific knowledge, techniques, and scientific methodology, also implying didactic abilities that primarily require the capacity of the advisor to establish a significant coherent learning relationship with their student (Dias et al., 2011).

For Viana (2008), the advisor and the student are two figures who are linked by a choice or by an obligation to share the knowledge-building journey. In this journey, both are people with feelings that fluctuate from one extreme to another, as in all human relationships.

The guidance process for academic studies is one of the most important teaching activities, although in Brazil it is neglected and lacks teacher training to develop the competences needed for it (Costa et al., 2015). For Nóbrega (2018), it is possible to perceive that in postgraduate programs the advisor-student relationship is unexplored and treated as an unimportant element for the student's education and conclusion of the dissertation or thesis. However, the author notes that the production of knowledge and research occurs in the actual contact between those involved, as the affectivity is interlinked with the scientific work, as in any practice that involves people.

During the development of theses or dissertations, it is essential for the advisors and students to know their attributions and establish a productive relationship that fosters the knowledge building. When the advisor does not perform their role, the relationship with the student becomes compromised and has negative effects on the knowledge-building process and on the quality of the scientific research (Leite \& Martins, 2006).

In Henri Wallon's (2007) Theory of Development, the teaching-learning process is considered a unit in which the interpersonal teacher-student relationship plays a definitive role, given that the affective-cognitive-motor dimensions work in an integrated way. Seeing the student in their entirety and reality is a challenge for the teacher, who is not normally trained in these joint dimensions (Mahoney \& Almeida, 2005).

Thus, the teacher's role of teaching has become, over the years, more comprehensive and complex, as they have gone from only fullfilling the role of conveyer of information and knowledge to being the student's guide or mediator during the knowledge-building process. This role requires training composed of diverse knowledge and attitudes that enable the student to assimilate the cognitive, affective, and behavioral concepts during the process of learning the curricular content, as these are linked to the student's performance in the learning environment (Ribeiro, 2010).

Leite (2012) emphasizes that the teacher-student relationship is also affective in nature and, as it develops, it causes positive or negative affective results in the relationship between the students and the curricular content developed, such as affinity or distance. Within this context, the teacher performs a relevant role in the knowledge building and has been the object of studies at different educational levels (Camargo, 2017; Pereira et al., 2016; Ribeiro et al., 2005; Veras \& Ferreira, 2010). Specifically in stricto sensu, positive and negative results are also found, originating from the dissertation and thesis guidance process. For example, Leite and Martins (2006) state that the building of knowledge during the guidance process is not a solitary action and that the relationship between the advisor and student is essential, as it is from the particular interaction with advisors that research will be produced that is capable of contributing to the growth and solidification of the science in the area studied.

Viana and Veiga (2010) highlight that the success of the relationship and of the scientific production requires the advisor and student to establish interaction rooted in dialogue, dedication, interest, discipline, responsibility, and commitment. These can inhibit the difficulties found both by advisors, such as a lack of time for their students to finish the activities within a certain timeframe, and by 
students, such as the unavailability of advisors to attend to them.

Costa et al. (2015) highlight that it is up to the advisor to guide the student during their education, as the student's development process is experiential and can occur based on their experiences in the classroom, in their relationship with teachers, course mates, and, especially, with the advisor themself. Falaster et al. (2017) argue that there is a relationship between the quality of the guidance and that of the student's academic development. The results of their study indicated that more experienced advisors with higher quality publications influence their students to produce quality publications instead of a high quantity.

Sheldon et al. (2015) evaluated the relevant qualities of advisors inherent to the student's knowledge, to their willingness, and to supporting their autonomy. The evidence indicated that supporting their autonomy was the most relevant factor in students' satisfaction and performance in relation to their advisors. The authors also revealed the relationship between the time the advisor makes available in the meetings with their students and the autonomy-supporting factor, given that this factor considers not only the way the student can acquire knowledge from their advisor, but also how the advisor helps them to develop interpersonal skills.

Within this context, the findings and the discussions that exist in the literature shed light on the relationship between the advisor and student, recognizing that the feelings experienced during the different phases of the guidance process can affect the quality of the activities developed and indicate elements that can be improved in that process.

\section{METHODOLOGY}

The descriptive research uses as its field of study students graduating from nine master's courses in the South Region of the country, which are affiliated with the following higher education institutions: the Regional University Foundation of Blumenau (FURB), the Federal University of Rio Grande (FURG), the State University of Maringá (UEM), the Federal University of Paraná (UFPR), the Federal University of Rio Grande do Sul (UFRGS), the Federal University of Santa Catarina (UFSC), the State University of the West of Paraná (Unioeste), the University of Vale do Rio dos Sinos (Unisinos), and the Communitary University of the Chapecó Region (Unochapecó). The sample is characterized as nonprobabilistic and was defined according to accessibility.
The South Region of Brazil was chosen to make the study economically and operationally viable. The data collection was operationalized in two stages: a survey and semistructured interviews. In the first stage, the online survey was carried out on the SurveyMonkey ${ }^{\circledR}$ platform with the aim of identifying the feelings experienced during the master's dissertation guidance process based on a questionnaire composed of two sections.

Section I contained the 10 phases that form the dissertation-building period and one question summarizing the whole process; with this, it was possible to capture the feelings experienced in each stage of building the dissertation. Table 1 shows the guidance phases that composed the questions in the research instrument.

Table 1

Phases of the dissertation-building period

1 - Discussion of the topic and research question

2 - Discussion of the objectives and contributions of the dissertation

3 - Discussion of the structure of the theoretical framework

4 - Discussion of the methodology

5 - Discussion of the adjustments suggested by the qualifying panel

6 - Discussion on the results analysis

7 - Discussion of the conclusions of the dissertation

8 - Discussion of the adjustments suggested by the defense panel

9 - Discussions on the article clippings generated by the master's dissertation

10 - Discussions on the continuity of studies in the program

General perception - Main positive and/or negative feelings experienced during the dissertation guidance process

Source: Elaborated by the authors. 
For each phase of the dissertation, the respondents were asked to indicate between one and three emojis with connotations of positive or negative feelings experienced in the respective phase of the research. Each emoji was given a number and the participant had to indicate the box corresponding to the emoji number. Ten emojis with negative connotations were shown and 10 with positive connotations. After indicating the emojis, in each phase an open text field was included for the respondent to indicate between three and five feelings experienced during that stage of the dissertation.

Novak et al. (2015) mention that emojis enable feelings to be expressed based on the maximization of non-verbal elements that draw attention and allow for greater understanding of the message by means of images. Thus, the use of emojis aims to share different affective representations in two different groups: positive

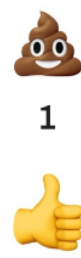

11
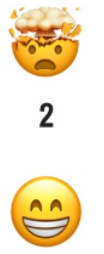

12

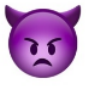

3

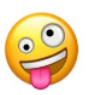

13

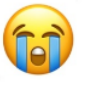

4

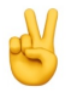

14

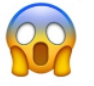

5

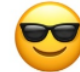

15 feelings and negative feelings. The study does not intend to discuss whether the respondents have unanimously labeled feelings for each emoji, but one of the aims of the interviews was to pluralize the representation of the feelings motivated by the use of the emojis indicated as the most frequent ones in this study. The selection of 20 emojis (10 positive and 10 negative) resulted from a search in published materials about those most used on a daily basis.

To validate the research survey externally, two research specialists (both affiliated with the post-graduate programs of the authors of the article) were contacted. It was certified that these specialists frequently use emojis to represent feelings in their day-to-day and that they are researchers from the area of accounting education. Their suggestions were accepted in full and resulted in the final version used in this study and presented in Figure 1.

Figure 1 Positive and negative emojis

Source: Elaborated by the authors.
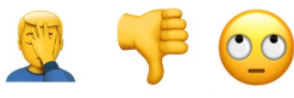

8
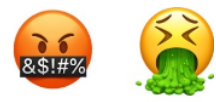

9

10
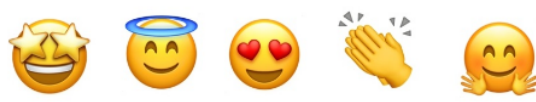

16

$17 \quad 18$

19

20

Section II aimed to characterize the research participants. Based on the answers obtained, it was possible to outline the profile of the 88 respondents according to Table 2 .

Table 2

Profile of the research participants

\begin{tabular}{lcc}
\hline & $\mathbf{n}$ & \% \\
\hline Age (years) & 5 & 5.68 \\
\hline Up to 25 & 54 & 61.36 \\
\hline From 26 to 35 & 22 & 25.00 \\
\hline From 36 to 45 & 6 & 6.82 \\
\hline From 46 to 55 & 1 & 1.14 \\
\hline Over 55 & & \\
\hline Region where they live & 2 & 2.27 \\
\hline Central-West & 5 & 5.68 \\
\hline Northeast & 0 & 0.00 \\
\hline North & 5 & 5.68 \\
\hline Southeast & 76 & 86.36 \\
\hline South & & \\
\hline Gender & 52 & \\
\hline Female & 59.09 \\
\hline Male & 36 & 40.91 \\
\hline Agender or non-binary & 0 & 0.00 \\
\hline Others & 0 & 0.00
\end{tabular}


Table 2

Cont.

\begin{tabular}{lll}
\hline & $\mathbf{n}$ & $\mathbf{\%}$ \\
\hline Changed city for master's & & \\
\hline Yes & 35 & 39.77 \\
\hline No & 53 & 60.23 \\
\hline Received financial assistance & & \\
\hline Yes, during the whole period of the master's & 40 & 45.45 \\
\hline Yes, during part of the period of the master's & 14 & 15.91 \\
\hline No & 34 & 38.64 \\
\hline
\end{tabular}

Source: Elaborated by the authors (2018).

Most of the respondents were of the female gender (59.09\%), 61.36\% are between 26 and 35 years-old, $86.39 \%$ live in the South Region, $60.23 \%$ did not change city to take their master's, and $45.45 \%$ received financial assistance during this period. The data obtained in the first stage of the study were analyzed using descriptive statistics. To identify and count the feelings described in the first stage of the research, the Text Analyzer ${ }^{\circledR}$ online tool was used.

In the second stage, semi-structured interviews were held with eight research participants, with the aim of understanding the experiences and feelings experienced during the guidance process, as well as identifying what the negative and positive emojis most indicated in the first stage represent in terms of feelings for the students finishing the master's. In the survey applied in the first stage, a field was included for the respondents to provide their email for participation in the second stage, which consisted of the interviews. The interview participants were chosen with the aim of covering the plurality of the courses. Thus, interviewees were chosen from different programs in order to minimize the risks of self-selection of opinions. The interview period occurred in January and February of 2019 and each one lasted approximately 30 minutes. The data saturation method was employed, in which the interviews were concluded when adding new participations did not add fresh and crucial evidence to the reports already gathered (Sampieri et al., 2013). Table 3 presents the script used in the semi-structured interviews.

Table 3

Semi-structured interview script

What types of feelings do the most indicated negative/positive emojis convey?

Do you think that during the guidance process positive or negative feelings prevailed in relation to the advisor? Could you describe why you had that sensation?

If you could go back in time, would you stick with the same master's advisor?

If the program presented a list of advisor names for continuing the studies into PhD level, would you stick with the same advisor?

Would you recommend your advisor to friends you wish well?

Source: Elaborated by the authors.

It is observed that the interviews focused on identifying feelings in the advisor-student relationship and not on the phases for elaborating the work (data collection, tabulation, and analysis).

Besides the pre-defined script, secondary questionnaires were carried out to obtain more details of the experiences and feelings experienced during the dissertation process. The evidence gathered were analyzed, as well as the descriptive statistics, using the collective subject discourse technique, which is "a way of retrieving and presenting the social representations obtained in empirical research" (Lefevre \& Lefevre, 2014, p. 503). Thus, the key expressions from the interviewees' speeches were identified, referring to the positive and negative feelings of the students graduating from the accounting master's and grouping the main ideas to build the collective subject discourse derived from these first-person reports, given that

the content of the opinions with a similar meaning present in different accounts are associated with each category, in order to use this content to form a synthesized account, drafted in the first-person singular, as if it were a collective speaking as an individual person. (Lefevre \& Lefevre, 2014, p. 503)

Afterwards, collective discourses were built to represent the positive and negative feelings of the interview participants. 


\section{RESULTS ANALYSIS}

The concepts proposed in the Frenchman Henri Wallon's Theory of Development contribute to the understanding of the affective dimension that feelings form part of. For Mahoney and Almeida (2005), understanding these concepts unveils important aspects to be considered for a satisfactory and constructive teaching-learning process. Table 4 shows the five feelings described and the three negative and positive emojis most indicated in each phase of the relationship between the advisor and student over the course of the dissertation. To identify the total feelings described, the Text Analyzer ${ }^{\circledR}$ online tool was used in the open answer field. In the case of a tie, all the feelings and/or emojis within the same percentage of occurrence are listed.

Table 4

Feelings and emojis with negative and positive connotations

\begin{tabular}{cc}
\hline Dissertation phases (Table 1) & Feelings with negative/positive connotations (\%) \\
\hline $1-$ Topic and research question & Anxiety $(4.79)$, fear $(4.10)$, anguish $(3.42)$, doubt $(2.39)$, uncertainty, \\
worry, and desperation $(2.05)$
\end{tabular}

TFM: 292

Joy (2.05), satisfaction (1.71), relief, happiness, and enthusiasm (1.37)

Anxiety (3.11), insecurity (2.07), doubt (2.07), solitude, anguish, confusion, fear, and worry (1.73)

2 - Objectives and contributions of the dissertation

TFM: 289

Satisfaction, confidence, calmness, enthusiasm, and determination (1.73)

Laboriousness (3.78), anxiety (2.27), solitude (1.89), tiredness and worry (1.51)

3 - Structure of the theoretical framework

TFM: 264

Calmness (3.41), enthusiasm (2.65), joy (2.27), relief, satisfaction, support, and determination (1.51)

Fear and anxiety (3.23), confusion (2.83), anguish and doubt (2.02)

4 - Methodology

TFM: 247

Satisfaction (2.02), joy, confidence, and support (1.62), assistance (1.21)

5 -Adjustments suggested by the qualifying panel

TFM: 269

Fear (2.97), anxiety (2.23), insecurity and nervousness (1.48) indignation, anger, and abandonment (1.11)

Calmness (4.83), joy (2.60), satisfaction (2.23), happiness and confidence $(1.85)$

Anguish, tiredness, difficulty, frustration, and fear (1.93)

6 - Results analysis

TFM: 258

Satisfaction (3.87), joy (3.48), confidence (2.71), enthusiasm (2.32), determination (1.93)

7 - Conclusions of the dissertation TFM: 252

Insecurity, solitude, anguish, fear, and absence (1.19)

Relief (5.95), satisfaction (4.36), joy and confidence (3.17), peace and pride (1.98)

Anger, solitude, anguish, ignorance, frustration, tiredness, and anxiety

8 -Adjustments suggested by the defense panel

TFM: 242
(0.82)

Calmness (6.61), relief, happiness, and satisfaction (5.37), joy (2.89)
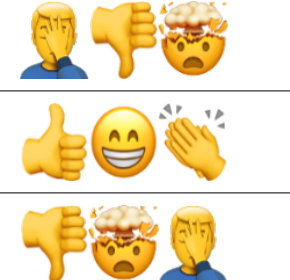

$B \cap$

Fed
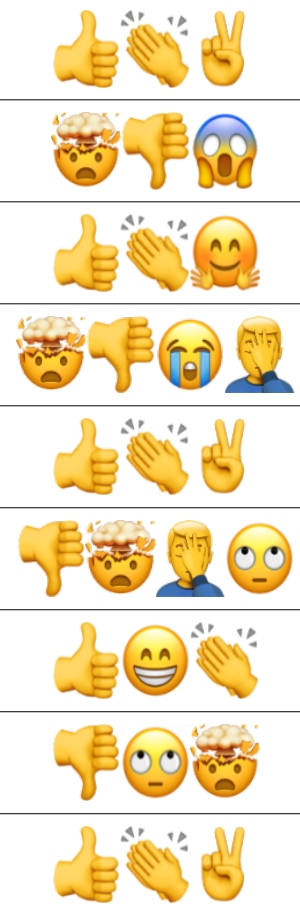
Table 4

Cont.

\begin{tabular}{|c|c|c|}
\hline Dissertation phases (Table 1) & Feelings with negative/positive connotations (\%) & Emojis \\
\hline \multirow{2}{*}{$\begin{array}{l}9 \text {-Article clippings generated by the } \\
\text { master's dissertation } \\
\text { TFM: } 275\end{array}$} & $\begin{array}{l}\text { Abandonment and difficulty (1.81), tiredness (1.45), anguish and } \\
\text { frustration (1.09) }\end{array}$ & \\
\hline & $\begin{array}{c}\text { Joy (4.00), satisfaction (3.27), accomplishment (2.90), calmness } \\
(2.18) \text {, enthusiasm (1.81) }\end{array}$ & \\
\hline \multirow{2}{*}{$\begin{array}{l}10-\text { Continuity of studies in the program } \\
\text { TFM: } 198\end{array}$} & Tiredness (3.03), anger, abandonment, frustration, and absence (1.51) & \\
\hline & $\begin{array}{l}\text { Joy }(3.03) \text {, calmness }(2.52) \text {, incentive, commitment, } \\
\text { satisfaction, support, enthusiasm, and pride ( } 2.02)\end{array}$ & \\
\hline \multirow{2}{*}{$\begin{array}{l}\text { General perception } \\
\text { TFM:325 }\end{array}$} & Anxiety (3.69), insecurity and fear (2.46), anger and anguish (1.53) & \\
\hline & $\begin{array}{l}\text { Joy and satisfaction (4.30), gratitude (3.69), resilience and support } \\
\qquad(2.15)\end{array}$ & \\
\hline
\end{tabular}

TFM = total feelings mentioned.

Source: Elaborated by the authors.

Through the feelings and emojis indicated by the respondents, it was noted that the relationship between the student and advisor in the topic discussion and research question phase was characterized by negative feelings of anxiety, fear, and doubts originating from the beginning of their interactions for building the research proposal. Similarly, during the discussion of the objectives and contributions of the dissertation stage, there was a predominance of insecurity, solitude, and anguish regarding the construction of the work and the established relationship. In the initial stages of the scientific research in which the study proposal is outlined, the advisor's attention is important, as the knowledge building does not occur in isolation and the interaction between the advisor and student is fundamental to reduce the scientific insecurity of the students and avoid damage in the following stages of building the dissertation (Leite \& Martins, 2006).

The relationship experienced in the period for discussing the structure of the theoretical framework was considered laborious and a generator of anxiety, tiredness, and solitude. In contrast, reports of feelings of satisfaction, confidence, support, and assistance from the advisor were also noted. The findings of Leite and Martins (2006) show that the student-advisor relationship is characterized by meetings that are asystematic and insufficient to meet the student's needs, which aligns with the feelings of solitude listed by the respondents. Nóbrega (2018) mentions that the advisor should specify, in their meetings with the students, readings and studies that enable the scientific research to be built, this being one of the aspects that can help in overcoming the difficulties in academic writing.
The methodology discussion phase was shown to be permeated primarily by fear, anxiety, and confusion. Nóbrega (2018) recommends that, in this period, the advisors encourage the students to carry out scientific readings and improve their academic writing, given that this ability is essential for the methodological development of the research (Nóbrega, 2018). Despite the evidence indicating that, when choosing students, advisors prefer those who have previous knowledge in the methodological field (Leite \& Martins, 2006), negative feelings permeate the relationship in this phase of the dissertation, seen as an essential stage for completing the work, as it involves the operationalization of the research.

In the phase for discussing the adjustments suggested by the qualifying panel, there was a predominance of positive feelings of calmness, joy, and satisfaction. This period marks the start of the academic research, a pre-requisite for subsequently defending the work (Nóbrega, 2018). It is understood that, despite being a stage that generates fear, anxiety, insecurity, and nervousness, the qualifying panel's approval tends to provide a more harmonious climate that directs the discussion of adjustments with the advisor, as the effects generated by the qualifying panel's approval promote calmness in the student.

Based on the qualification phase, an increase was perceived in the indication of positive feelings. In this context, the student's maturity collaborated so that, in the discussion phase regarding the results analysis, there was a sensation of satisfaction, joy, confidence, enthusiasm, and determination. Also worth highlighting are the feelings of tiredness and exhaustion in the relationship between the advisor and student. In the phase for discussions and 
conclusions of the dissertation, there was a predominance of feelings of relief, satisfaction, joy, confidence, peace, and pride.

In the phase for discussing the adjustments suggested by the defense panel, positive feelings of calmness, relief, happiness, satisfaction, and joy were observed. Nonetheless, there are reports of negative feelings of anger, solitude, anguish, ignorance, frustration, tiredness, and anxiety. In the research stage, the feelings of satisfaction and frustration originating from the relationship with the advisor may be mirrored in the quality of the dissertation perceived by the student. The reports shown in the research of Leite and Martins (2006) converge with this aspect, as the quality of the scientific research depends on the dialogue between the student and advisor, engagement, empathy originating from this relationship, and indications by the advisor of paths to be followed by the student.

The discussions on the article clippings generated by the master's dissertation were permeated by positive feelings of joy, satisfaction, accomplishment, calmness, and enthusiasm. In a lower percentage, there was an indication of difficulties and abandonment during the process of discussions inherent to the articles originating from the dissertation.

With relation to the discussions on the continuity of studies in the program, feelings of joy, calmness, incentive, commitment, satisfaction, support, enthusiasm, and pride were indicated, which are aspects that can promote the student's desire to continue with their academic training in the same post-graduate program as the master's. However, there were feelings of tiredness, anger, abandonment, frustration, and absence of the advisor regarding these discussions, leading to non-continuity of academic training in the post-graduate program.

Actions formed and displayed based on antagonistic feelings can generate conflicts in the advisor-student relationship and make the teaching-learning process more difficult, as it involves a hierarchical relationship (Silva, 2005). The Wallonian theory helps to recognize the students' affective displays as signs of situations experienced in a positive or negative way.

Thus, understanding how affectivity manifests through feelings enables the definition of strategies suited to the specificities of each student (Gratiot-Alfandéry, 2010). In order to broaden the understanding of these feelings, semi-structured interviews were conducted and collective subject discourses were built based on the speeches of the eight graduating students interviewed. First, the three negative and positive connotation emojis most indicated in the survey were chosen and the interviewees were asked to describe the feelings that those emojis represent in the relationship between the student and advisor. Table 5 shows the percentage of indications of each emoji with a negative connotation, highlighting the most frequent ones in each phase.

Table 5

Dispersion of the negative emojis in the dissertation phases

\begin{tabular}{|c|c|c|c|c|c|c|c|c|c|c|}
\hline \multirow[b]{2}{*}{ Phases } & \multicolumn{10}{|c|}{ Emojis (\%) } \\
\hline & 1 & 2 & 3 & 4 & 5 & 6 & 7 & 8 & 9 & 10 \\
\hline 1 & 4.88 & 17.01 & 2.56 & 12.20 & 16.85 & 11.40 & 11.95 & 2.82 & 8.51 & 15.38 \\
\hline 2 & 4.88 & 10.20 & 5.13 & 9.76 & 7.87 & 14.91 & 10.69 & 9.86 & 12.77 & 5.13 \\
\hline 3 & 9.76 & 8.84 & 5.13 & 4.88 & 6.74 & 8.77 & 10.06 & 5.63 & 8.51 & 15.38 \\
\hline 4 & 9.76 & 10.20 & 15.38 & 8.54 & 14.61 & 9.65 & 10.69 & 8.45 & 17.02 & 7.69 \\
\hline 5 & 14.63 & 7.48 & 10.26 & 8.54 & 8.99 & 6.14 & 6.92 & 2.82 & 4.26 & 7.69 \\
\hline 6 & 7.32 & 8.84 & 7.69 & 10.98 & 8.99 & 7.89 & 7.55 & 2.82 & 6.38 & 2.56 \\
\hline 7 & 4.88 & 5.44 & 5.13 & 4.88 & 4.49 & 5.26 & 6.29 & 8.45 & 0.00 & 7.69 \\
\hline 8 & 2.44 & 4.08 & 5.13 & 0.00 & 2.25 & 4.39 & 5.66 & 8.45 & 8.51 & 5.13 \\
\hline 9 & 9.76 & 4.08 & 10.26 & 4.88 & 3.37 & 8.77 & 8.18 & 14.08 & 12.77 & 7.69 \\
\hline 10 & 12.20 & 2.72 & 10.26 & 4.88 & 4.49 & 5.26 & 11.32 & 28.17 & 2.13 & 7.69 \\
\hline GP & 19.51 & 21.09 & 23.08 & 30.49 & 21.35 & 17.54 & 10.69 & 8.45 & 19.15 & 17.95 \\
\hline Total [n (\%)] & $41(100)$ & $\begin{array}{c}147 \\
(100)\end{array}$ & $\begin{array}{c}39 \\
(100)\end{array}$ & $\begin{array}{c}82 \\
(100)\end{array}$ & $\begin{array}{c}89 \\
(100)\end{array}$ & $\begin{array}{c}114 \\
(100)\end{array}$ & $\begin{array}{c}159 \\
(100)\end{array}$ & $\begin{array}{c}71 \\
(100)\end{array}$ & $\begin{array}{c}47 \\
(100)\end{array}$ & $\begin{array}{c}39 \\
(100)\end{array}$ \\
\hline
\end{tabular}

Note: The values are presented in percentages (\%), which represent the distribution of the emoji in each phase of the dissertation. The total line presents the number of mentions of each emoji. The most frequent emojis in each phase are highlighted in gray. $G P=$ General Perception.

Source: Elaborated by the authors. 
The most indicated emoji with a negative connotation was 7 , which was indicated 159 times during the dissertation-building phases, followed by emoji 2 , with 147 indications, and by 6 , with 114 indications. By means of the interviewees' reports, it was possible to build a collective subject discourse that explains why these emojis were the most indicated in the interviewees' perception, as presented in Table 6.

Table 6

Representation of the most-indicated emojis involving negative feelings

Represents dynamism, negativity, and disagreement with the way the guidance was given. Dissatisfaction and disappointment with the guidance gave rise to feelings of disapproval and conflict, meaning the guidance was marked as a negative experience.

Represents those students who had a misalignment of ideas with the advisor. The attitudes and ideas did not converge, generating confusion. There were conflicts in the relationship, generating stress, nervousness, anguish, desperation, and mental exhaustion.

There were disappointments during the course of the master's, having an impact in the form of dissatisfaction, anger, and frustration.

Source: Elaborated by the authors.

The negative emojis represent feelings generated by turbulences in the guidance process. The feeling of abandonment and differences in attitude between the advisor and students lead to feelings that affect the construction of the research. Falaster et al. (2017) observed that the teacher's availability and support of the student's autonomy interfere in the result of the scientific research. It is important for course coordinations to observe these aspects throughout guidance processes.

Similarly, the most indicated positive connotation emojis were identified through the construction of Table 7.

Table 7

Dispersion of the positive emojis in the dissertation phases

\begin{tabular}{|c|c|c|c|c|c|c|c|c|c|c|}
\hline \multirow[b]{2}{*}{ Phases } & \multicolumn{10}{|c|}{ Emojis (\%) } \\
\hline & & 12 & 13 & 14 & 15 & 16 & $\stackrel{17}{\bigodot}$ & 18 & 19 & 20 \\
\hline 1 & 5.67 & 11.43 & 6.52 & 4.32 & 2.33 & 12.15 & 9.09 & 8.91 & 6.19 & 8.09 \\
\hline 2 & 8.67 & 9.71 & 13.04 & 8.63 & 8.14 & 8.41 & 2.27 & 1.98 & 7.73 & 9.56 \\
\hline 3 & 8.00 & 12.00 & 8.70 & 10.07 & 11.63 & 8.41 & 15.91 & 5.94 & 5.67 & 8.82 \\
\hline 4 & 9.33 & 6.86 & 8.70 & 7.19 & 6.98 & 8.41 & 4.55 & 6.93 & 7.73 & 6.62 \\
\hline 5 & 11.67 & 7.43 & 6.52 & 10.79 & 5.81 & 7.48 & 11.36 & 3.96 & 10.31 & 12.50 \\
\hline 6 & 9.00 & 6.86 & 9.78 & 10.07 & 13.95 & 7.48 & 11.36 & 12.87 & 8.25 & 6.62 \\
\hline 7 & 11.67 & 13.14 & 9.78 & 8.63 & 13.95 & 7.48 & 11.36 & 12.87 & 10.31 & 6.62 \\
\hline 8 & 9.67 & 8.57 & 7.61 & 15.83 & 11.63 & 8.41 & 9.09 & 11.88 & 12.89 & 9.56 \\
\hline 9 & 8.67 & 7.43 & 3.26 & 10.07 & 8.14 & 9.35 & 6.82 & 10.89 & 9.79 & 8.82 \\
\hline 10 & 8.33 & 6.86 & 6.52 & 6.47 & 4.65 & 8.41 & 9.09 & 7.92 & 6.19 & 6.62 \\
\hline GP & 9.33 & 9.71 & 19.57 & 7.91 & 12.79 & 14.02 & 9.09 & 15.84 & 14.95 & 16.18 \\
\hline Total [n (\%)] & $\begin{array}{c}300 \\
(100)\end{array}$ & $\begin{array}{c}175 \\
(100)\end{array}$ & $\begin{array}{c}92 \\
(100)\end{array}$ & $\begin{array}{c}139 \\
(100)\end{array}$ & $\begin{array}{c}86 \\
(100)\end{array}$ & $\begin{array}{c}107 \\
(100)\end{array}$ & $\begin{array}{c}44 \\
(100)\end{array}$ & $\begin{array}{c}101 \\
(100)\end{array}$ & $\begin{array}{c}194 \\
(100)\end{array}$ & $\begin{array}{c}136 \\
(100)\end{array}$ \\
\hline
\end{tabular}

Note: The values are presented in percentages (\%), which represent the distribution of the emoji in each phase of the dissertation. The total line presents the number of mentions of each emoji. The most frequent emojis in each phase are highlighted in gray.

$G P=$ General Perception .

Source: Elaborated by the authors.

The most indicated positive connotation emoji was 11, with 300 indications, followed by 19, with 194 indications, and by 12 , with 175 indications. The collective subject discourses that represent the interviewees' perceptions are shown in Table 8. 
Table 8

Representation of the most indicated emojis involving positive feelings

Represents praise for the dedication, relief about the research results, overcoming the obstacles and reworking, alignment and conclusion of the research in a positive way and with good feelings about accomplishing the work.

Represents feelings of gratitude for the knowledge built with the advisor, happiness, joy, and pride about the work in partnership with the advisor, recognition by the teacher of the student's effort in developing the research, and the establishment of a harmonious relationship.

Represents overcoming obstacles, enthusiasm about the guidance, conclusion of stages of the dissertation, and a feeling of pride.

Source: Elaborated by the authors.

Next, collective subject discourses were built for questions that composed the script of the semi-structured interviews. Table 9 shows the discourses for the feelings that prevailed in the relationship.

Table 9

Feelings that prevailed

Do you think that during the guidance process positive or negative feelings in relation to the advisor prevailed? Could you describe why you had this sensation?

My guidance process was very painful and stressful; I felt abandoned, neglected, alone, and with no support from my advisor.

It was very frustrating in terms of the human relationship. There was a lack of good judgement. I think that they lacked sensitivity in relation to me as a student, they were never available and that was infuriating; I had to seek help from course mates and other professors on the program and, if it weren't for them, I wouldn't have coped.

I became a master in human resistance rather than in accounting, and what helped a lot in this difficult phase was the support of the friends I did the master's with.

We had a good relationship, they were very receptive, I always had access to them and all the decisions were shared, I always had their help, I didn't feel alone, they gave me the freedom to grow in my own time.

I have good memories and feelings of gratitude, partnership, friendship, collectivity, and comradeship.

Source: Elaborated by the authors.

The collective discourse with a negative connotation draw attention to the attitude of abandonment and negligence taken by the advisor regarding the development of the student's research. These reports explain the presence of feelings of abandonment, absence, and insecurity, such as those indicated in the survey. This lack of monitoring generates psychological consequences in the student and affects the quality of the academic work developed, where the support to overcome difficulties comes from friends and other professors who accompany them in their academic journey. The discourse with a positive connotation indicates that the harmonious relationship between the advisor and student implies the student gradually maturing academically, with this relationship being strengthened through feelings of gratitude and comradeship.

The findings contribute to the existing evidence in the literature, for example in the paper by Viana and Veiga (2010), who reinforce the idea that a good relationship with the advisor is essential for the conclusion of the work, in which the advisors' availability, care, and receptiveness favor the completion of the research. In contrast, feelings of solitude and abandonment, as well as the advisor's unavailability, cause damage to the advisor-student relationship and, consequently, to the quality of the work.

Wallon's theory values the teacher-student relationship and the educational environment as essential elements in the person's full development (Ferreira \& Acioly-Régnier, 2010). In this theory, the educational environment is formed of the human relationships, physical objects, and knowledge, and committed to the student's evolution in a practice that involves the social and individual dimension (Galvão, 2000). Within this context, the guidance is a joint process in which the development of the work occurs in the communication established between the parties involved, by means of the analytical and constructive vision of the advisor, who performs the role of stimulating the student's desire to carry out the research and seek knowledge and their intellectual autonomy (Viana, 2008). Table 10 shows the discourses relating to the exchanges with the advisor, to the continuity of guidance, and to recommending the advisor to friends. 
Table 10

Collective discourse regarding exchanges with the advisor and guidance continuity

If you could go back in time, would you stick with the same master's advisor?

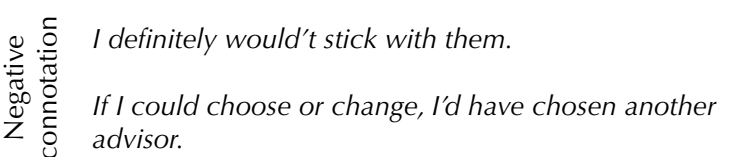

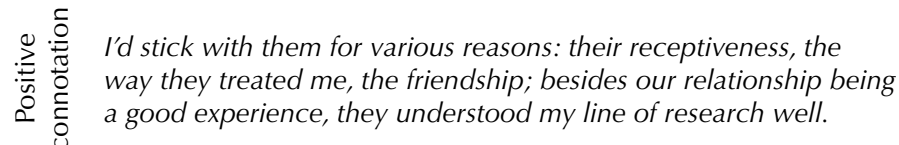

If the program presented a list of advisor names for continuing the studies into PhD level, would you stick with the same advisor?

No, absolutely not.

They left a lot to be desired regarding the dissertation,

besides being very arrogant and not respecting the

students.

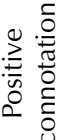

Yes, they would be my first choice, because of the alignment and synchronism we had in our relationship as well as their technical knowledge, in that they know what stage the research is at in my area, what is lacking, or what can be researched.

Would you recommend your advisor to friends you wish well?

Source: Elaborated by the authors.

The reports denote that those who had negative experiences during the master's guidance process would choose to change guidance and would not continue with the guidance into $\mathrm{PhD}$ level. Thus, the results are able to direct the focus toward the organization and management of the guidance of the accounting post-graduate programs investigated. The allocation of guidance should not be seen as something that is fixed, but should instead allow the student or advisor to choose to interrupt the guidance if there are any ambiguous situations. Misalignment of work styles and personality between the student and advisor can cause friction and weaken the academic development process.

The discourses with a positive connotation reinforce valued aspects that even transcend the advisors' technical qualities. The reports indicate that greater affective proximity with the advisors fosters synchronism in the development of the scientific research and maximizes the desire to continue the guidance process into $\mathrm{PhD}$ level, as well as to recommend the advisor to others. Within this scope, Leite and Martins (2006) show that students tend to value the affective characteristics of advisors, while advisors prioritize students' technical skills. It is believed that the master's adaptation period collaborates in affective qualities being valued by the students, given that over the course of the master's they face various challenges that require the support of others.

Table 11 shows the discourses built regarding other aspects in which the advisor was more important in the process and influenced the quality of the academic work.

Table 11

Other notes

\section{Other important points regarding the guidance process}

The guidance stage where I most felt the advisor's absence was at the beginning, to be able to align the research, as I believe the advisor's main contribution is at the start, when determining the topic, discussing the justification, and giving reassurance regarding the path that should be taken.

I built the idea and objectives on my own and that definitely influenced the quality of my work and my excitement to carry it out.

I wasn't able to resolve simple questions because we students don't have the vision, the experience, which is the role of the advisor, to indicate the right path, to discuss, to guide.

I think the advisors generally need to be more aware of the weight of responsibility they have in their students' life, because there's a whole emotional structure involved in building the dissertation and the pressure we put on ourselves; the master's is a difficult stage. 
Source: Elaborated by the authors.

It is noted that the initial phase of the dissertation building is characterized by greater dependence on the advisor, when the student anxiously waits for the initial contact with their advisor to discuss the work. The student's expectation is to engage in a dialogue and, from then on, have a direction. The advisor, in turn, expects the student to have an interesting research idea that fits their research line. This is a decisive phase in building a relationship that will strengthen throughout the process of elaborating the dissertation, positively or negatively affecting the quality of the work (Viana, 2008).

The reports are aligned with the feelings indicated in the survey, given that in the initial stages there is a predominance of fear, insecurity, doubt, and anguish originating from the relationship with the advisor and from the dissertation building. In this sense, the advisor was described as the student's guide, where their role was to indicate the paths to be taken and help in defining the overall scope of the research. The collective subject discourse reveals that their essentiality directly affects the quality of the work developed, which is also argued by Sheldon et al. (2015), as well as the emotional state of the students throughout the dissertation-building process.
Thus, numerous feelings are experienced during the dissertation guidance process. It is perceived that these feelings provide drive or cause obstacles over the course of building the research, being factors that interfere in the quality of the academic work and that affect the student's psychological state. Distance between the advisor and the student is a barrier in the guidance process and to the success of dissertations, besides being a determinant of the feelings of anguish and solitude displayed by the students. Thus, it is essential for the guidance process to be based on respect and democracy with the aim of driving the advisor-student relationship in a harmonious way, promoting dialogue, and reducing the pressure and autocracy over the students (Alves et al., 2012).

The relationship between affectivity and learning has been considered an essential element for discussing different themes, such as the advisor-student relationship, academic performance, and motivation, among others (Tassoni \& Santos, 2013). Within this context, the concept of affectivity can be observed in the discussions about feelings, as addressed in this study, in which their manifestation is perceived as a response to the events experienced during the dissertation guidance period.

\section{CONCLUDING REMARKS}

The relationship between the advisor and student has been indicated as a relevant element in the construction of academic research. Focusing on master's dissertations, the advisor figure plays a predominant role in the student's adaptation to the academic demands and in overcoming the adversities that can occur along the way. The evidence in the literature (Alves et al., 2012; Falaster et al., 2017; Leite \& Martins, 2006) shows that the alignment, interaction, and feelings experienced during the guidance process are able to affect both the quality of the scientific research and the student's academic development.

The findings of this research indicated the predominance of negative feelings at the start of the guidance process, when anxiety, fear, anguish, and insecurity characterize the first phases of the relationship with the advisor. Over the course of the dissertation, other feelings were reported, such as abandonment, confusion, and frustration, highlighting that the accumulation of stressful elements originating from the dissertation building and from the relationship with the advisor marks the stages of the dissertation and causes obstacles to development in stricto $s e n s u$. In contrast, there were reports of a maximization of positive feelings, such as joy, satisfaction, happiness, and calmness, which collaborate with the establishment of an affective relationship based on comradeship, support, and an understanding of the student's difficulties.

The relationship established during the guidance is able to affect the likelihood of the student continuing their education, as well as being linked to the quality of the activities developed in stricto sensu. The discordances 
found by the students regarding their advisors may be due to a lack of professionalization and clear guidance concerning the advisor's role in the Brazilian university environment (Massi \& Giordan, 2017). It is suggested that post-graduate programs monitor and evaluate the quality of their guidance by consulting the students. Similarly, advisors should be consulted with the aim of verifying the development of the student and their research.

The definition of rules and the possibility of changing guidance could also be addressed as a formal process in stricto sensu courses that is carried out without obstacles. Misalignments in work styles and personality could thus be addressed as something that is common, with their being structures in the programs for overcoming these adversities.

The representations obtained through the emojis and the indications made by the participants express the plurality of feelings that permeate all the phases of dissertation building. As proposed in Henri Wallon's (2007) Theory of Development, the social representations obtained in the study indicate that the feelings are perpetuated and consolidated over time, and the concerns weigh on the impact that these feelings cause in the development of the students' academic journey, as well as on the perpetuation of these practices when they themselves carry out teaching activities.

Thus, periodic monitoring of the students' emotional state and the availability of channels for helping them to overcome difficulties that can arise throughout the research are presented as practical implications provided by the evidence. In the theoretical field, building social representations based on feelings represented by emojis presents an advance for the topic, as emojis are visual representations that are widely used on an everyday basis and are able to convey a plurality of feelings that it would be hard to show through other forms of communication.

The limitations of this study consist of the absence of research that uses emojis to represent feelings that would enable a possible comparative analysis. On the other hand, this limitation can also be understood as one of the methodological contributions of the research. For future research, we suggest analyzing the formal mechanisms of post-graduate programs, in order to verify how conflicts in the relationship between advisors and students are addressed by advisors and course coordinators. Moreover, covering and comparing the different regions of the country could outline the profile of the relationships produced in stricto sensu accounting courses and enable benchmarking to be practiced among the programs.

\section{REFERENCES}

Alves, V. M., Espindola, I. C. P., \& Bianchetti, L. (2012). A relação orientador-orientando na pós-graduação stricto sensu no Brasil: A autonomia dos discentes em discussão. Revista Educação em Questão, 43(29), 135-156.

Camargo, P. D. S. A. S. (2017). Representações sociais de docentes da EJA: Afetividade e formação docente. Educação \& Realidade, 42(4), 1567-1589.

Costa, F. J., Sousa, S. C. T., \& Silva, A. B. (2015). Um modelo para o processo de orientação na pós-graduação. Revista Brasileira de Pós-Graduação, 11(25).

Del Prette, Z. A. P., Paiva, F., Martini, M. L., \& Del Prette, A. (2005). Contribuições do referencial das habilidades sociais para uma abordagem sistêmica na compreensão do processo de ensino-aprendizagem. Interações, 10(20), 57-72.

Dias, S. M. R. C., Patrus, R., \& Magalhães, Y. T. de. (2011). Quem ensina um professor a ser orientador? Proposta de um modelo de orientação de monografias, dissertações e teses. Administração: Ensino e Pesquisa, 12(4), 697-727.

Falaster, C., Ferreira, M. P., \& Gouvea, D. M. R. de. (2017). $\mathrm{O}$ efeito da publicação científica do orientador na publicação dos seus orientados. Revista de Administração Contemporânea, 21(4), 458-480. https://doi.org/10.1590/19827849rac2017160118
Ferreira, A. L., \& Acioly-Régnier, N. M. (2010). Contribuições de Henri Wallon à relação cognição e afetividade na educação. Educar em Revista, 26(36), 21-38.

Galvão, I. (2000). Henri Wallon: uma concepção dialética do desenvolvimento infantil. Vozes.

Gratiot-Alfandéry, H. (2010). Henri Wallon/Hélène GratiotAlfandéry. Tradução e organização Patrícia Junqueira. Fundação Joaquim Nabuco/Editora Massangana. https://doi. org/10.1007/BF02195303

Lefevre, F., \& Lefevre, A. M. C. (2014). Discurso do sujeito coletivo: Representações sociais e intervenções comunicativas. Texto Contexto Enfermagem, 23(2), 502-507.

Leite, G. A., Filho, \& Martins, G. de A. (2006). Relação orientador-orientando e suas influências na elaboração de teses e dissertações. Revista de Administração de Empresas, 46[Especial], 99-109. https://doi.org/10.1590/S003475902006000500008

Leite, S. A. D. S. (2012). Afetividade nas práticas pedagógicas. Temas em Psicologia, 20(2), 355-368.

Levecque, K., Anseel, F., De Beuckelaer, A., van der Heyden, J., \& Gisle, L. (2017). Work organization and mental health problems in PhD students. Research Policy, 46(4), 868-879. https://doi.org/10.1016/j.respol.2017.02.008 
Mahoney, A. A., \& Almeida, L. R. de. (2005). Affection and teaching-learning process: Contributions of Henri Wallon. Psicologia da Educação, 20(1), 11-30. http://pepsic.bvsalud. org/pdf/psie/n20/v20a02.pdf

Massi, L., \& Giordan, M. (2017). Formação do orientador de pesquisas acadêmicas: Um estudo bibliográfico nacional e internacional. Revista Brasileira de Pós-Graduação, 14. https://doi.org/10.21713/2358-2332.2017.v14.1375

Nascimento, L. F. (2010). Modelo Capes de avaliação: Quais as consequências para o triênio 2010-2012? Administração: Ensino e Pesquisa, 11(4), 579. https://doi.org/10.13058/ raep.2010.v11n4.130

Nóbrega, M. H. da. (2018). Orientandos e orientadores no século XXI: Desafios da pós-graduação. Educação \& Realidade, 43(3), 1055-1076. https://doi.org/10.1590/2175623674407

Novak, P. K., Smailovi, J., Sluban, B., \& Mozeti, I. (2015). Sentiment of emojis. PloS One, 10(12), 1-22. https://doi. org/10.1371/journal.pone.0144296

Pereira, A. L., Silva, B. D. D., \& Almeida, L. R. D. (2016). Afetividade no contexto acadêmico: Percepção de mestrandos de um curso oferecido em regime b-learning. In Livro de Atas do VII Congresso Mundial de Estilos de Aprendizagem (p. 1648-1659).

Reis, V. T., Prata, M. A. R., \& Soares, A. B. (2012). Habilidades sociais e afetividade no contexto escolar: Perspectivas envolvendo professores e ensino-aprendizagem. Psicologia Argumento, 30(69), 347-357.

Ribeiro, M. L. (2010). A afetividade na relação educativa. Estudos de Psicologia, 27(3), 403-412.
Ribeiro, M. L., Jutras, F., \& Louis, R. (2005). Análise das representações sociais de afetividade na relação educativa. Psicologia da Educação, (20), 31-54.

Sampieri, R. H., Collado, C. F., \& Lucio, M. del P. B. (2013). Metodologia de pesquisa (5a. ed). Penso.

Sheldon, K. M., Garton, B., Orr, R., \& Smith, A. (2015). The advisor quality survey: Good college advisors are available, knowledgeable, and autonomy supportive. Journal of College Student Development, 56(3), 261-273.

Silva, A. R. C. (2005). Sentimentos e emoções: Um estudo com professores e alunos do curso de medicina veterinária. In Anais da XXVIII Reunião Anual da ANPEd (p. 1-18).

Tassoni, E. C. M., \& Leite, S. A. da S. (2013). Afetividade no processo de ensino-aprendizagem: As contribuições da teoria walloniana. Educação, 36(2), 262-271. https://doi. org/10.1097/00004714-198504000-00001

Tassoni, E. C. M., \& Santos, A. N. M. D. (2013). Afetividade, ensino e aprendizagem: Um estudo no GT20 da ANPEd. Psicologia Escolar e Educacional, 17(1), 65-76.

Veras, R. da S., \& Ferreira, S. P. A. (2010). A afetividade na relação professor-aluno e suas implicações na aprendizagem, em contexto universitário. Educar em Revista, (38), 219-235. https://doi.org/10.1590/S0104-40602010000300015

Viana, C. M. Q. Q. (2008). A relação orientador-orientando na pós-graduação stricto sensu. Linhas Críticas, 14(26), 93-110.

Viana, C. M. Q. Q., \& Veiga, I. P. A. (2010). O diálogo acadêmico entre orientadores e orientandos. Educação, 33(3), 222-226.

Wallon, H. (2007). A evolução psicológica da criança. Martins Fontes. 